\title{
INDIRECT TAXATION AND ECONOMIC GROWTH RELATIONSHIP: EMPIRICAL EVIDENCE FROM ASIAN COUNTRIES
}

\author{
Zia Ur Rehman*, Muhammad Azam Khan ${ }^{\dagger}$ \& \\ Muhammad Tariq ${ }^{*}$
}

\begin{abstract}
The chief aim of the study to explore the consequence of indirect taxes on economic growth in the Asian Countries and used the panel data of 12 (twelve) Asian countries for period of 1996 to 2018 and used PMG techniques to estimate the model. This study found that the gross capital formation, political stability, labor force, inward FDI, human capital and taxes on goods and services have encouraging while domestic credit to private investment have adverse and significant consequence on economic growth in long term. The labor force and taxes on goods and services and political stability have encouraging and noteworthy consequence on economic growth in short term while gross capital formation, human capital, inward FDI, DCP have insignificant short-term consequence on economic growth. The TGS (taxes on goods and services) have encouraging and noteworthy effect on economic growth in Bangladesh, Iran, Nepal, Turkey, Indonesia, Malaysia, Thailand and Bhutan while have harmful and significant effect on economic growth in Pakistan, Sri Lanka, Philippine and Japan. This study concluded that the indirect taxation has encouraging and noteworthy effect on economic growth in the Asia. Moreover, the effect of indirect taxes was very from country to country dues its economic situation. The Political stability (PS) have also noteworthy effect on economic growth. This study recommended that indirect taxes are more helpful to collect the revenue with the presences of political stability.
\end{abstract}

\footnotetext{
(Corresponding author) PhD Scholar, Faculty of Business \& Economics, Department of Economics Abdul Wali Khan University, Mardan, KP-Pakistan, Email ID: ziamarwat1980@gmail.com.

$\dagger$ Muhammad Azam Khan, Faculty of Business \& Economics, Department of Economics Abdul Wali Khan University, Mardan, KP-Pakistan.

* Muhammad Tariq, Faculty of Business \& Economics, Department of Economics, Abdul Wali Khan University, Mardan, KP-Pakistan
} 
Keywords: Indirect taxation; economic growth; panel data; Asia

\section{Background of the study}

The main responsibility of the government to collect revenue to finance the expenditure. The main and the oldest sources of revenue was taxation. There were some other motives can be achieved by the government through taxation like economic stabilization, to minimize the income inequality and to provision of public goods and services (Abiola \& Asiweh, 2012). The chief function of a taxation policy was to collect the adequate revenue which was essential to fulfil the expenditure and repayment the government debt (Okoye \& Ezejiofor, 2014). Tax system was itself a best instrument to mobilize the country internal resources and creating a good environment to promote economic growth(Ayuba, 2014). Therefore, the tax system has dual benefit, on one side its mandatory for the gathering of revenue to finance the public expenditure and on other side it promotes economic growth.

This study based on the endogenous growth theory presented by King and Rebelo (1990) stated that government taxation policy can influence economic growth permanently in the short and long run. Cremer, Pestieau, and Rochet (2001) stated that taxes on income were sufficient because the individuals are not same according to the qualitative characteristics and the indirect taxes were more appropriate for the optimal tax policy. According toDahlby (2003) that the collection of indirect taxes were transparent. According to Ilaboya and Mgbame (2012) that the supporters of indirect taxation believe that these taxes were enhanced growth, while other believes that indirect taxation does not have statistically noteworthy consequence on economic growth. Some argues that the indirect taxes were the main cause of higher inflation and widen the income inequality. Atkinson and Stiglitz (1976) present the theorem that the government dependents on taxes on income mainly because each individual have own utility function and earning ability, therefore, no need to impose the indirect taxes.Cremer and Gahvari (1995) stated that there were presence of uncertainty in the individual income, therefore, taxes goods and services are mandatory factors of the optimal tax policy. Naito (2007) using the endogenous growth model and argues that the indirect taxes were increase the welfare in the presence of nonlinear taxation on income.

There are lot of literature available on the relationship between the taxation and it's types means direct and indirect taxation and economic growth, but there no clear theoretical and empirical evidence is available that the effect of taxation and it's types have negative or positive effect on economic growth and used different data and techniques to estimate the data. This study concentrations on the effect of indirect taxes on economic growth. According to Poterba, Rotemberg, and Summers (1985) ,Madsen 
and Damania (1996), Harberger (1964), Greenidge and Drakes (2010), Emran and Stiglitz (2005), Musaga (2007), Greenidge and Drakes (2010) and Ilaboya and Mgbame (2012) that indirect taxes have harmful and statistically noteworthy effect on economic growth and Kneller, Bleaney, and Gemmell (1999), Arisoy and Unlukaplan (2010), Scarlett (2011), Bâzgan (2018), Laura (2019) and Yanikkaya and Turan (2020) found that indirect taxes have encouraging and statistically noteworthy effect on economic growth and Ilaboya and Mgbame (2012) found that indirect taxes have insignificant consequence on economic growth. Therefore, this study was conducted to find the answer of the controversial question that the effect indirect taxes on economic growth.

The chief objective of the study to investigate the relationship of indirect taxation on economic growth of Asian countries. This study will be more beneficial for the governments to design the tax policy and to influence the economic growth. This study is contributed to the existing literature and different from other studies because it first time used this data set of twelve Asian countries and used PMG techniques to analyze the data. The political stability as controlled variable, which is one of the most important factors to collect the maximum revenue and spend on developmental projects. This study was organized as that background of the study was present in part one, existing literature review in part second, empirical strategy in part three, data analysis and discussion in part four and conclusion in part five and references at the end.

\section{Literature Review}

Musaga (2007) found that indirect taxes have statistically noteworthy and negative consequence on economic growth in Uganda. Greenidge and Drakes (2010) found that the effect of total and indirect taxes have adverse effect on economic growth in the short and long run for Barbados economy. Scarlett (2011) used the quarterly data from 1990-2010 and ARDL techniques to evaluate the model to examine the effect of tax policy on Jamaica's economic growth. He concluded that growing the revenue through indirect taxes were more encouraging long run growth effect. While, increasing revenue through income taxes were too harmful to economic growth.Kadir, Idris, and Mohamed (2011) examined the effect of indirect taxation and gross national products by using three-monthly data for the period 2000-2008 for Malaysian economy. They found negative correlation between the GNP and other taxes, sales taxes and import duties while service taxes, excise and export duties have positive correlation with GNP. They concluded that indirect taxes was enhanced growth.Ilaboya and Mgbame (2012) observed the effect of indirect taxation on growth and used data for the years 1980 to 2011 for Nigerian and ARDL techniques to 
estimate the data. They found that the indirect taxes have negative but statistically insignificant consequence on economic growth.

Bâzgan (2018) examined the consequence of indirect and direct taxes on economic growth in Romania and used quarterly data from 2009-2017 and VAR model to estimate the data. He found that an rise in indirect taxes have promote the economic growth and increase in the direct taxes have harm the economic growth. Laura (2019) observed the effect of indirect taxes on economic growth and used the time series data from 1981-2018 and OLS and ECM techniques to estimate the data. He found that excise and customs duties and VAT have encouraging and statistically significant consequence on economic growth while excise and customs duties have insignificant consequence on economic growth. But, the overall consequence of indirect taxes have noteworthy on economic growth. Yanikkaya and Turan (2020) surveyed the long run association among the tax rates and economic growth and used the panel data setfrom 1970-1999 for Nigerian economy and GMM techniques to analyze the data. They found that the convert the tax revenue from the taxes on individual income to property and consumption taxes, keep the overall tax revenue constant, have statistically noteworthy and positive consequence on economic growth.

\section{Empirical Strategy}

This study used the panel data for 12 Asian countries named Iran, Nepal, Bangladesh, Pakistan, Turkey, Sri Lanka, Indonesia, Phosphine, Thailand, Japan and Bhutan for period of 1996-2018. This study used the modified proposed model of Arnold et al. (2011) by using the panel ECM framework. Ormaechea and Yoo (2012),Baiardi, Profeta, Puglisi, and Scabrosetti (2017)and Azam (2019) also used the Pesaran, Shin, and Smith (1997) constructed model.

$$
\begin{aligned}
& \Delta G D P G_{i t}=\beta_{0 t}+\emptyset_{i} G D P G_{i, t-1}+\beta_{1} G K F_{i t}+\beta_{2} L F_{i t}+\beta_{3} H K_{i t}+\beta_{4} P S_{i t}+\beta_{5} F D I_{i t}+ \\
& \beta_{6} D C P_{i t}+\beta_{7} T G S_{i t}+\sum_{i=1}^{n} \gamma_{i j} \Delta G D P G_{i t}+\sum_{i=0}^{n} \vartheta_{1 j} \Delta G K F_{i t}+\sum_{i=0}^{n} \vartheta_{2 j} \Delta L F_{i t}+\sum_{i=0}^{n} \vartheta_{3 j} \Delta H K_{i t}+ \\
& \sum_{i=0}^{n} \vartheta_{4 j} \Delta P S_{i t}+\sum_{i=0}^{n} \vartheta_{5 j} \Delta F D I_{i t}+\sum_{i=0}^{n} \vartheta_{6 j} \Delta D C P_{i t}+\sum_{i=0}^{n} \vartheta_{7 j} \Delta T G S_{i t}+\omega_{i t}
\end{aligned}
$$

Where

$$
\begin{gathered}
\emptyset_{i}=-\left(1-\sum_{i=1}^{p} \gamma_{i j}\right), \beta_{i}=\sum_{i=1}^{p} \vartheta_{i j} \\
\gamma_{i j}=-\sum_{m=j+1}^{p} \gamma_{i m}, j=1,2, \ldots, p-1 \text { and } \vartheta_{i j}=-\sum_{m=j+1}^{p} \vartheta_{i m}, j=1,2, \ldots, q-1, i \\
=1,2, \ldots, n
\end{gathered}
$$

where

$$
i=0,1,2, \ldots . . n, \emptyset_{i} \text { is the correction term from the short run to long run equilibrium. }
$$




\section{Table 1: Variable Description}

\begin{tabular}{|c|c|c|c|c|}
\hline S\# & Variable & Unite & Source & Symbol \\
\hline 1 & GDP growth & percentage & WDI (2019) & GDPG \\
\hline 2 & $\begin{array}{l}\text { Labor force (as percentage of } \\
\text { total population) }\end{array}$ & percentage & WDI (2019) & $\mathrm{LF}$ \\
\hline 3 & $\begin{array}{l}\text { Secondary school enrollment } \\
\text { (\% gross enrollment) proxy } \\
\text { for human capital }\end{array}$ & percentage & WDI (2019) & HK \\
\hline 4 & $\begin{array}{l}\text { Gross capital formation (as } \\
\% \text { age of GDP) }\end{array}$ & percentage & WDI (2019) & GKF \\
\hline 5 & Political Stability & $\begin{array}{l}\text { Rank from } \\
\text { for lower to } \\
\text { higher } \\
(1 \text { to } 100)\end{array}$ & $\begin{array}{c}\text { The global } \\
\text { economy website, } \\
2019\end{array}$ & PS \\
\hline 6 & $\begin{array}{l}\text { Inward Foreign Direct } \\
\text { Investment ( } \% \text { of GDP) }\end{array}$ & percentage & WDI (2019) & FDI \\
\hline 7 & $\begin{array}{l}\text { Domestic credit to private } \\
\text { sector (\%age of GDP) }\end{array}$ & percentage & WDI (2019) & DCP \\
\hline 8 & $\begin{array}{l}\text { Taxes on goods and services } \\
\text { (\%age of total revenue) } \\
\text { proxy for indirect taxes }\end{array}$ & percentage & WDI (2019) & TGS \\
\hline
\end{tabular}

Note: WDI stand for World Development Indicator

\section{Estimation Techniques}

This study used the panel unit root test because the panel data permitted to strong statistical test and test statistics tends to normal distribution instead of nonconventional distribution. In this study we used panel unit root tests Levin, Lin and Chu t test introduced by Levin, Lin, and Chu (2002), Im, Pesaran \& Shin W-test introduced by Im, Pesaran, and Shin (2003) and Augmented Dicky Fuller test- Fisher Chi-square test introduced by Maddala and $\mathrm{Wu}$ (1999). The PMG techniques was used to estimate the long and short run coefficient for whole panel and the short run coefficient for each country constructed by Pesaran, Shin, and Smith (1999) to estimate the model. We also apply panel cointegration test constructed by Kao (1999) with the $H_{0}$ that there are no-cointegration in the heterogeneous and homogeneous panels. 


\section{Results and Discussion}

Table 2 presents the descriptive statistics and correlation among the variables. The mean of GDPG, GKF, HK, LF, PS, DCP, FDI and TGS are $4.453,28.521,69.072, \quad 42.596,37.721,60.580,1.352$ and 28.928 respectively and the standard deviation are $3.277,9.349,20.963,8.125$, $19.299,50.795,1.352$ and 12.202 respectively. The skewedness values of all variables are lies in the normality range between -1.96 to 1.96 , furthermore, GDPG, HK and TGS are negatively skewed while GKF, LF, PS, DCP and FDI are positively skewed. The kurtosis value of variables is positive and have heavy tail.

The correlation between the GDP growth and GKF, HK, LF, PS, DCP, FDI and TGS are $0.337,0.049,0.015,0.007,-0.313,0.155$ and 0.048 respectively. GKF, HK, LF, PS, FDI and TGS have positive correlation with GDP growth, means if these variables increase the GDP growth will be also increases, while the DCP have negative correlation with GDP growth, means DCP increases the GDP growth will be decreases.

Table 2: Summary of Descriptive Statistics and Correlation Matrix

\begin{tabular}{lcccccccc}
\hline & GDPGit & GKFit & HKit & LFit & PSit & DCPit & FDIit & TGSit \\
\hline Mean & 4.453 & 28.521 & 69.072 & 42.596 & 37.721 & 60.580 & 1.352 & 28.928 \\
Median & 4.969 & 25.490 & 72.463 & 41.678 & 35.000 & 37.765 & 1.027 & 30.166 \\
Maximum & 17.926 & 61.702 & 99.763 & 59.106 & 76.000 & 221.289 & 6.435 & 56.132 \\
Minimum & -13.127 & 15.000 & 23.000 & 25.413 & 1.000 & 6.675 & -2.757 & 2.200 \\
Std. Dev. & 3.277 & 9.349 & 20.963 & 8.125 & 19.299 & 50.795 & 1.352 & 12.202 \\
Skewness & -1.139 & 1.512 & -0.343 & 0.196 & 0.311 & 1.308 & 1.057 & -0.382 \\
Kurtosis & 8.159 & 5.211 & 2.065 & 2.127 & 2.317 & 3.563 & 4.388 & 2.771 \\
GDPGit & 1 & & & & & & & \\
GKFit & 0.337 & 1 & & & & & & \\
HKit & 0.049 & 0.014 & 1 & & & & & \\
LFit & 0.015 & 0.065 & 0.215 & 1 & & & & \\
PSit & 0.007 & 0.462 & 0.253 & 0.323 & 1 & & & \\
DCPit & -0.313 & -0.104 & 0.480 & 0.580 & 0.545 & 1 & & \\
FDIit & 0.155 & -0.063 & 0.103 & 0.097 & 0.096 & 0.220 & 1 & \\
TGSit & 0.048 & -0.422 & 0.248 & 0.447 & -0.169 & 0.198 & 0.052 & 1 \\
\hline
\end{tabular}


Table 3: Results Panel Unit Root Tests with Constant

\begin{tabular}{|c|c|c|c|c|c|c|c|}
\hline \multirow[b]{2}{*}{ Variable } & \multicolumn{2}{|c|}{$\begin{array}{l}\text { LLC Test } \\
\text { (P-value) }\end{array}$} & \multicolumn{2}{|c|}{$\begin{array}{l}\text { IP\&S W Test } \\
\text { (P-value) }\end{array}$} & \multicolumn{2}{|c|}{$\begin{array}{l}\text { ADF-Fisher } X^{2} \text { Test } \\
\text { (P-value) }\end{array}$} & \multirow[t]{2}{*}{ Decision } \\
\hline & $\begin{array}{c}\text { At } \\
\text { Level }\end{array}$ & $\begin{array}{l}\text { At } 1^{\text {st }} \\
\text { Dif }\end{array}$ & $\begin{array}{c}\text { At } \\
\text { Level }\end{array}$ & $\begin{array}{l}\text { At } 1^{\text {st }} \\
\text { Dif }\end{array}$ & At Level & At $1^{\text {st }}$ Dif & \\
\hline GDPG $_{\text {it }}$ & $\begin{array}{l}-6.1983^{*} \\
(0.0000)\end{array}$ & ----- & $\begin{array}{l}-7.1413 * \\
(0.0000)\end{array}$ & ------ & $\begin{array}{l}97.9023^{*} \\
(0.0000)\end{array}$ & ----- & $\mathrm{I}(0)$ \\
\hline $\mathbf{G K F}_{\text {it }}$ & $\begin{array}{l}-2.4589 * \\
(0.0070)\end{array}$ & ----- & $\begin{array}{l}-2.5126^{*} \\
(0.0060)\end{array}$ & ----- & $\begin{array}{l}55.9306 * \\
(0.0002)\end{array}$ & ----- & $\mathrm{I}(0)$ \\
\hline $\mathbf{L F}_{\text {it }}$ & $\begin{array}{l}-0.1385 \\
(0.4449)\end{array}$ & $\begin{array}{l}-6.8921 * \\
(0.0000)\end{array}$ & $\begin{array}{l}-0.6473 \\
(0.2587)\end{array}$ & $\begin{array}{r}-10.231^{*} \\
(0.0000)\end{array}$ & $\begin{array}{l}32.4583 \\
(0.1160)\end{array}$ & $\begin{array}{l}141.979^{*} \\
(0.0000)\end{array}$ & $\mathrm{I}(1)$ \\
\hline $\mathbf{H K}_{\mathrm{it}}$ & $\begin{array}{c}0.1111 \\
(0.5442)\end{array}$ & $\begin{array}{c}-9.2621^{*} \\
(0.000)\end{array}$ & $\begin{array}{c}1.3188 \\
(0.9064)\end{array}$ & $\begin{array}{r}-10.794 * \\
(0.0000)\end{array}$ & $\begin{array}{l}25.4695 \\
(0.3806)\end{array}$ & $\begin{array}{l}146.417 * \\
(0.0000)\end{array}$ & $\mathrm{I}(1)$ \\
\hline $\mathbf{P S}_{\text {it }}$ & $\begin{array}{l}-1.3862 \\
(0.0828)\end{array}$ & $\begin{array}{l}-8.3576^{*} \\
(0.0000)\end{array}$ & $\begin{array}{l}-0.7794 \\
(0.2179)\end{array}$ & $\begin{array}{l}-8.0688 \\
(0.0000)\end{array}$ & $\begin{array}{l}27.6557 \\
(0.2748)\end{array}$ & $\begin{array}{l}108.659 \\
(0.0000)\end{array}$ & $\mathrm{I}(1)$ \\
\hline FDI $_{i t}$ & $\begin{array}{l}-3.0960^{*} \\
(0.0010)\end{array}$ & --- & $\begin{array}{l}-4.0365^{*} \\
(0.0000)\end{array}$ & --- & $\begin{array}{l}59.2525^{*} \\
(0.0001)\end{array}$ & ---- & $\mathrm{I}(0)$ \\
\hline $\mathbf{D C P}_{\text {it }}$ & $\begin{array}{l}-0.9285 \\
(0.1766)\end{array}$ & $\begin{array}{l}-5.1104 * \\
(0.0000)\end{array}$ & $\begin{array}{c}0.2167 \\
(0.5858)\end{array}$ & $\begin{array}{l}-5.8421 * \\
(0.0000)\end{array}$ & $\begin{array}{c}31.819 \\
(0.1315)\end{array}$ & $\begin{array}{l}78.4861 * \\
(0.0000)\end{array}$ & $\mathrm{I}(1)$ \\
\hline $\mathbf{T G S}_{\text {it }}$ & $\begin{array}{c}-2.169^{* *} \\
(0.0151)\end{array}$ & $\begin{array}{c}-9.7575^{*} \\
(0.0000)\end{array}$ & $\begin{array}{l}-1.5938 \\
(0.0555)\end{array}$ & $\begin{array}{c}-10.651^{*} \\
(0.0000)\end{array}$ & $\begin{array}{l}36.0135 \\
(0.0547)\end{array}$ & $\begin{array}{c}144.230^{*} \\
(0.0000)\end{array}$ & $\begin{array}{c}1(0), \mathrm{I}(1) \\
\& \mathrm{I}(1)\end{array}$ \\
\hline
\end{tabular}

Note: $* \& * *$ represent $1 \% \& 5 \%$ level of significance respectively.

Table 3 indicated the panel unit root test results, which depicted that GDPG, GKF and FDI have zero degree order of integration and LF, HK, PS and DCP have first degree of order of integration, the all three panel unit root test have same results. The LLC test shows that TGS have zero-degree order of integration while IP\&S W test and ADF- Fisher chi square test shows that TGS have first degree of order of integration. The pattern of the data has mix order of integration which recommend using the PMG techniques to estimate the model.

Table 4 illustrations the PMG and panel co-integration test results. The gross capital formation and inward FDI have encouraging and noteworthy long run effect on GDP growth but have insignificant short run effect. If one percent rise in GKF will bring increase in the GDP growth by $0.1502 \%$ in long term. The same outcome was showed by (Karim \& Khan, 2018; Rehman, Tariq, \& Khan, 2018) and opposite results was shown by Devarajan, Swaroop, and Zou (1996). The labor force has also encouraging 
and noteworthy consequence on economic growth in long term and short term. If one percent increases in the labor force will bring rise in the GDP growth by 0.1713 percent in long term and 0.2810 percent in short term. Solow (1956) stated that sustainable growth was achieved by physical capital and labor force, while Kneller et al. (1999), presented negative and significant effect over economic growth. The HK has statistically noteworthy and positive consequence on GDP growth in long term but have insignificant consequence in short term. The political stability has encouraging and statistically noteworthy consequence on economic growth in long term and short term. If one unit increase to political stability will rise in GDP growth by $0.0477 \%$ in long term and 0.2108 percent in short term. The same results was given by (Feng, 1997) and Cox and Weingast (2018). The DCP has negative and significant effect on economic growth in the long term while have insignificant effect on economic growth in the short run. If one percent rise in the DCP will cut the GDP growth by $0.1461 \%$ in long term. The TGS have encouraging and noteworthy consequence on economic growth in long term and short run. If $1 \%$ rise in the revenue from TGS will bring rise in GDP growth by $0.2312 \%$ in long-term and 0.1277 percent in short term. This result was confirmed the Kneller et al. (1999), Arisoy and Unlukaplan (2010), Scarlett (2011), Bâzgan (2018), Laura (2019) and Yanikkaya and Turan (2020) findings that the indirect taxation have encouraging consequence on economic growth and oppose with the results of Poterba et al. (1985), Madsen and Damania (1996), Harberger (1964), Greenidge and Drakes (2010), Emran and Stiglitz (2005), Musaga (2007), Greenidge and Drakes (2010) and Ilaboya and Mgbame (2012) that indirect taxes have adverse and statistically noteworthy outcome on economic growth. The results of significantly positive impact of inward FDI on growth is in accord with Azam and Ahmed (2015), Abdullah et al. (2019), and Azam et al. (2020). The error correction term values are -0.5859 and significant, means that there are $59 \%$ speed of correction from short run to long run equilibrium. The Kao Residual cointegration test value is -7.7262 and significant, therefore, reject the $H_{0}$ that there are no cointegration in the variables. 
Table 4: PMG Results on Taxes on Goods and Services and Economic Growth

\begin{tabular}{|c|c|c|c|c|}
\hline Variable & Coefficient & Std. Error & t-Statistic & Prob. \\
\hline \multicolumn{5}{|c|}{ Long Run Coefficients } \\
\hline $\mathrm{GKF}_{\text {it }}$ & $0.1502 *$ & 0.0350 & 4.2860 & 0.0000 \\
\hline $\mathrm{LF}_{\mathrm{it}}$ & $0.1713 *$ & 0.0406 & 4.2217 & 0.0000 \\
\hline $\mathrm{HK}_{\mathrm{it}}$ & $0.0378 *$ & 0.0141 & 2.6871 & 0.0080 \\
\hline $\mathrm{PS}_{\mathrm{it}}$ & $0.0477 *$ & 0.0094 & 5.0674 & 0.0000 \\
\hline $\mathrm{FDI}_{\mathrm{it}}$ & $0.3707 *$ & 0.0745 & 4.9731 & 0.0000 \\
\hline $\mathrm{DCP}_{\mathrm{it}}$ & $-0.1461 *$ & 0.0142 & -10.2920 & 0.0000 \\
\hline $\mathrm{TGS}_{\mathrm{it}}$ & $0.2312 *$ & 0.0492 & 4.6997 & 0.0000 \\
\hline \multicolumn{5}{|c|}{ Short Run Coefficients } \\
\hline $\mathrm{ECM}$ & $-0.5859 *$ & 0.1944 & -3.0139 & 0.0030 \\
\hline $\mathrm{D}\left(\mathrm{GKF}_{\mathrm{it}}\right)$ & 0.0003 & 0.0509 & 0.0065 & 0.9948 \\
\hline $\mathrm{D}\left(\mathrm{LF}_{\mathrm{it}}\right)$ & $0.2810 * *$ & 0.1088 & 2.5825 & 0.0108 \\
\hline $\mathrm{D}\left(\mathrm{HK}_{\mathrm{it}}\right)$ & 0.0527 & 0.2272 & 0.2319 & 0.8169 \\
\hline $\mathrm{D}\left(\mathrm{PS}_{\mathrm{it}}\right)$ & $0.2108 * *$ & 0.0884 & 2.3842 & 0.0184 \\
\hline $\mathrm{D}\left(\mathrm{FDI}_{\mathrm{it}}\right)$ & 0.0321 & 0.0528 & 0.6074 & 0.5445 \\
\hline $\mathrm{D}\left(\mathrm{DCP}_{\mathrm{it}}\right)$ & 0.3437 & 0.3892 & 0.8831 & 0.3786 \\
\hline $\mathrm{D}\left(\mathrm{TGS}_{\mathrm{it}}\right)$ & $0.1277 * *$ & 0.0644 & 1.9825 & 0.0493 \\
\hline $\mathrm{C}$ & 0.0600 & 0.1183 & 0.5071 & 0.6129 \\
\hline \multicolumn{5}{|c|}{ Kao Residual Cointegration Test } \\
\hline \multicolumn{3}{|c|}{ t-statistics (P-value) } & \multicolumn{2}{|c|}{$-7.7262(0.0000)$} \\
\hline
\end{tabular}

Note: $* \& * *$ represent $1 \% \& 5 \%$ level of significance respectively.

Table 5(a) and 5(b) shows the short run coefficient for each country encompassed in the data set. The political stability has encouraging and significant consequence on economic growth in the all included countries in the model. The TGS have encouraging and noteworthy effect on economic growth in Bangladesh, Iran, Nepal, Turkey, Indonesia, Malaysia, Thailand and Bhutan while have harmful and significant consequence on economic growth in Pakistan, Sri Lanka, Philippine and Japan. The error correction term values were found adverse and noteworthy for all countries except Turkey. 
Table 5(a): PMG Short Run Results on Indirect Taxes and Economic Growth Country Wise

\begin{tabular}{|c|c|c|c|c|c|c|}
\hline Variables & Bangladesh & Iran & Nepal & Pakistan & $\begin{array}{c}\text { Sri } \\
\text { Lanka }\end{array}$ & Turkey \\
\hline ECM & $\begin{array}{l}-0.1548^{*} \\
{[0.0052]} \\
(0.0001)\end{array}$ & $\begin{array}{l}-0.2212 * \\
{[0.0267]} \\
(0.0037)\end{array}$ & $\begin{array}{l}-0.8808 * \\
{[0.0192]} \\
(0.0000)\end{array}$ & $\begin{array}{l}-0.7264 * \\
{[0.0193]} \\
(0.0000)\end{array}$ & $\begin{array}{l}-0.6190 * \\
{[0.0130]} \\
(0.0000)\end{array}$ & $\begin{array}{c}0.0054 \\
{[0.0126]} \\
(0.6951)\end{array}$ \\
\hline $\begin{array}{c}\mathrm{D}\left(\mathrm{GDPG}_{\mathrm{t}}\right. \\
(-1))\end{array}$ & $\begin{array}{c}0.0104 \\
{[0.0073]} \\
(0.2498)\end{array}$ & $\begin{array}{c}0.0462 * * * \\
{[0.0161]} \\
(0.0644)\end{array}$ & $\begin{array}{l}0.3766^{*} \\
{[0.0119]} \\
(0.0001)\end{array}$ & $\begin{array}{l}0.2416 * \\
{[0.0081]} \\
(0.0001)\end{array}$ & $\begin{array}{l}0.0602 * \\
{[0.0040]} \\
(0.0006)\end{array}$ & $\begin{array}{l}0.0364 * * \\
{[0.0087]} \\
(0.0247)\end{array}$ \\
\hline $\mathrm{D}\left(\mathrm{GKF}_{\mathrm{t}}\right)$ & $\begin{array}{l}0.1896^{*} \\
{[0.0182]} \\
(0.0019)\end{array}$ & $\begin{array}{l}1.0552 * \\
{[0.0773]} \\
(0.0009)\end{array}$ & $\begin{array}{l}0.1929 * \\
{[0.0066]} \\
(0.0001)\end{array}$ & $\begin{array}{l}0.5598 * \\
{[0.0176]} \\
(0.0001)\end{array}$ & $\begin{array}{l}0.1677^{*} \\
{[0.0108]} \\
(0.0006)\end{array}$ & $\begin{array}{c}0.3886^{*} \\
{[0.0620]} \\
(0.0082)\end{array}$ \\
\hline $\mathrm{D}\left(\mathrm{LF}_{\mathrm{t}}\right)$ & $\begin{array}{c}1.0386 * * * \\
{[0.3367]} \\
(0.0539)\end{array}$ & $\begin{array}{c}-0.4937 \\
{[0.3293]} \\
(0.2308)\end{array}$ & $\begin{array}{l}0.3974 * * \\
{[0.0778]} \\
(0.0145)\end{array}$ & $\begin{array}{l}1.0731 * \\
{[0.0815]} \\
(0.0009)\end{array}$ & $\begin{array}{c}0.1742^{* * *} * \\
{[0.0598]} \\
(0.0618)\end{array}$ & $\begin{array}{c}0.0117 \\
{[0.1143]} \\
(0.9251)\end{array}$ \\
\hline $\mathrm{D}\left(\mathrm{HK}_{\mathrm{t}}\right)$ & $\begin{array}{l}0.1431 * \\
{[0.0013]} \\
(0.0000)\end{array}$ & $\begin{array}{c}0.1687 \\
{[0.0561]} \\
(0.0574)\end{array}$ & $\begin{array}{l}0.0622 * \\
{[0.0016]} \\
(0.0000)\end{array}$ & $\begin{array}{c}0.4333^{*} \\
{[0.0070]} \\
(0.0000)\end{array}$ & $\begin{array}{l}1.0225^{*} \\
{[0.0403]} \\
(0.0001)\end{array}$ & $\begin{array}{c}0.2998 * \\
{[0.0100]} \\
(0.0001)\end{array}$ \\
\hline $\mathrm{D}\left(\mathrm{PS}_{\mathrm{t}}\right)$ & $\begin{array}{c}0.1224 * \\
{[0.0037]} \\
(0.0001)\end{array}$ & $\begin{array}{c}0.5182 \\
{[0.0160]} \\
(0.0001)\end{array}$ & $\begin{array}{l}0.0926^{*} \\
{[0.0016]} \\
(0.0000)\end{array}$ & $\begin{array}{l}0.0633^{*} \\
{[0.0037]} \\
(0.0004)\end{array}$ & $\begin{array}{l}0.0435^{*} \\
{[0.0014]} \\
(0.0001)\end{array}$ & $\begin{array}{l}0.0567 * * \\
{[0.0126]} \\
(0.0206)\end{array}$ \\
\hline $\mathrm{D}\left(\mathrm{FDI}_{\mathrm{t}}\right)$ & $\begin{array}{l}0.2686 * * \\
{[0.0526]} \\
(0.0146)\end{array}$ & $\begin{array}{c}0.6632 \\
{[0.7508]} \\
(0.4421)\end{array}$ & $\begin{array}{l}4.3505^{*} \\
{[0.4584]} \\
(0.0025)\end{array}$ & $\begin{array}{c}0.1429 \\
{[0.0694]} \\
(0.1316)\end{array}$ & $\begin{array}{c}-0.0307 \\
{[0.1113]} \\
(0.8004)\end{array}$ & $\begin{array}{c}0.2152 \\
{[0.3944]} \\
(0.6233)\end{array}$ \\
\hline $\mathrm{D}\left(\mathrm{DCP}_{\mathrm{t}}\right)$ & $\begin{array}{l}-0.0387 * \\
{[0.0023]} \\
(0.0005)\end{array}$ & $\begin{array}{l}0.3526^{*} \\
{[0.0271]} \\
(0.0010)\end{array}$ & $\begin{array}{l}0.0713 * \\
{[0.0001]} \\
(0.0000)\end{array}$ & $\begin{array}{l}0.1715^{*} \\
{[0.0029]} \\
(0.0000)\end{array}$ & $\begin{array}{l}-0.0640 * \\
{[0.0030]} \\
(0.0002)\end{array}$ & $\begin{array}{l}0.1565^{*} \\
{[0.0126]} \\
(0.0011)\end{array}$ \\
\hline $\mathrm{D}\left(\mathrm{TGS}_{\mathrm{t}}\right)$ & $\begin{array}{l}0.0942 * \\
{[0.0079]} \\
(0.0013)\end{array}$ & $\begin{array}{c}0.7000 * * * \\
{[0.2232]} \\
(0.0518)\end{array}$ & $\begin{array}{l}0.1045^{*} \\
{[0.0065]} \\
(0.0005)\end{array}$ & $\begin{array}{l}-0.5702 * \\
{[0.0218]} \\
(0.0001)\end{array}$ & $\begin{array}{c}-0.1592^{*} \\
{[0.0036]} \\
(0.0000)\end{array}$ & $\begin{array}{l}0.7205^{*} \\
{[0.0756]} \\
(0.0024)\end{array}$ \\
\hline $\mathrm{C}$ & $\begin{array}{c}-0.7296 \\
{[0.3232]} \\
(0.1092)\end{array}$ & $\begin{array}{c}-0.5328 \\
{[0.5769]} \\
(0.4239)\end{array}$ & $\begin{array}{c}-9.3782 \\
{[4.8061]} \\
(0.1461)\end{array}$ & $\begin{array}{c}-6.1208 * * * \\
{[2.1053]} \\
(0.0621)\end{array}$ & $\begin{array}{c}- \\
6.6343 * * * \\
{[2.6045]} \\
(0.0841)\end{array}$ & $\begin{array}{c}-1.0692 \\
{[0.7354]} \\
(0.2420)\end{array}$ \\
\hline
\end{tabular}

Note: *, **\&*** represent $1 \%, 5 \%$ \& $10 \%$ level of significance respectively. 
Table 5(b): PMG Short Run Results on Indirect Taxes and Economic Growth Country Wise

\begin{tabular}{|c|c|c|c|c|c|c|}
\hline Variable & Indonesia & Malaysia & Philippine & Thailand & Japan & Bhutan \\
\hline \multirow{3}{*}{ ECM } & $-0.5745^{*}$ & $-0.7693^{*}$ & $-0.1091^{*}$ & $-0.1194^{*}$ & $-0.1105^{*}$ & $-0.5509 *$ \\
\hline & {$[0.0258]$} & {$[0.0166]$} & {$[0.0114]$} & {$[0.0124]$} & {$[0.0083]$} & {$[0.0253]$} \\
\hline & $(0.0004)$ & $(0.0000)$ & $(0.0025)$ & $(0.0024)$ & $(0.0009)$ & $(0.0002)$ \\
\hline \multirow{4}{*}{$\begin{array}{c}\mathrm{D}\left(\mathrm{GDPG}_{\mathrm{t}}\right. \\
(-1))\end{array}$} & $0.0644 *$ & $0.0651 *$ & $-0.1480 *$ & $0.1911^{*}$ & $0.2089 *$ & $0.1559^{*}$ \\
\hline & {$[0.0050]$} & {$[0.0036]$} & [0.0079] & {$[0.0078]$} & [0.0139] & {$[0.0066]$} \\
\hline & $(0.0010)$ & $(0.0004)$ & $(0.0003)$ & $(0.0001)$ & $(0.0006)$ & $(0.0002)$ \\
\hline & $0.1340 *$ & $0.5575^{*}$ & $0.0182 * * *$ & $0.7053^{*}$ & 0.0246 & $0.0620^{*}$ \\
\hline \multirow[t]{3}{*}{$\mathrm{D}\left(\mathrm{GKF}_{\mathrm{t}}\right)$} & [0.0056] & {$[0.0250]$} & {$[0.0065]$} & {$[0.0253]$} & {$[0.1852]$} & {$[0.0071]$} \\
\hline & $(0.0002)$ & $(0.0002)$ & $(0.0677)$ & $(0.0001)$ & $(0.9027)$ & $(0.0031)$ \\
\hline & $0.9968 *$ & $0.1481 * *$ & $1.2239 *$ & -0.0604 & $1.2260 *$ & $0.4071 *$ \\
\hline \multirow[t]{3}{*}{$\mathrm{D}\left(\mathrm{LF}_{\mathrm{t}}\right)$} & {$[0.0350]$} & {$[0.0321]$} & {$[0.0450]$} & {$[0.0751]$} & {$[0.1413]$} & [0.0289] \\
\hline & $(0.0001)$ & $(0.0191)$ & $(0.0001)$ & $(0.4797)$ & $(0.0032)$ & $(0.0008)$ \\
\hline & $0.0236 * * *$ & $0.2714^{*}$ & $0.0422 *$ & $0.3321 *$ & 0.0409 & $0.0268 * *$ \\
\hline \multirow[t]{3}{*}{$\mathrm{D}\left(\mathrm{HK}_{\mathrm{t}}\right)$} & {$[0.0101]$} & [0.0084] & [0.0059] & {$[0.0122]$} & {$[0.1115]$} & [0.0064] \\
\hline & $(0.1014)$ & $(0.0001)$ & $(0.0057)$ & $(0.0001)$ & $(0.7383)$ & $(0.0252)$ \\
\hline & $0.0467 *$ & $0.1081 *$ & $0.0065^{*}$ & -0.0075 & $0.1544 * *$ & $0.2040 *$ \\
\hline \multirow[t]{3}{*}{$\mathrm{D}\left(\mathrm{PS}_{\mathrm{t}}\right)$} & {$[0.0018]$} & {$[0.0007]$} & {$[0.0003]$} & {$[0.0051]$} & [0.0359] & [0.0098] \\
\hline & $(0.0001)$ & $(0.0000)$ & $(0.0003)$ & $(0.2424)$ & $(0.0231)$ & $(0.0002)$ \\
\hline & -0.0191 & $-0.7603^{*}$ & $-0.2467^{*}$ & -0.0844 & 0.5828 & $-0.9575^{*}$ \\
\hline \multirow[t]{3}{*}{$\mathrm{D}\left(\mathrm{FDI}_{\mathrm{t}}\right)$} & [0.0291] & [0.0404] & [0.0312] & [0.0447] & [1.0077] & {$[0.0430]$} \\
\hline & $(0.5591)$ & $(0.0003)$ & $(0.0042)$ & $(0.1556)$ & $(0.6036)$ & $(0.0002)$ \\
\hline & $0.6571^{*}$ & $-0.0267 *$ & $0.2581 *$ & $-0.1573 *$ & $-0.0219 *$ & $0.1741^{*}$ \\
\hline \multirow[t]{3}{*}{$\mathrm{D}\left(\mathrm{DCP}_{\mathrm{t}}\right)$} & {$[0.0057]$} & [0.0024] & [0.0031] & {$[0.0021]$} & [0.0012] & [0.0189] \\
\hline & $(0.0000)$ & $(0.0015)$ & $(0.0000)$ & $(0.0000)$ & $(0.0003)$ & $(0.0027)$ \\
\hline & $0.1928 * *$ & $0.0248^{*}$ & $-0.5495^{*}$ & $0.3583^{*}$ & $-0.2087^{*}$ & $0.0124 * * *$ \\
\hline \multirow[t]{3}{*}{$\mathrm{D}\left(\mathrm{TGS}_{\mathrm{t}}\right)$} & {$[0.0638]$} & {$[0.0034]$} & [0.0181] & {$[0.0374]$} & {$[0.0234]$} & [0.0043] \\
\hline & $(0.0567)$ & $(0.0053)$ & $(0.0001)$ & $(0.0024)$ & $(0.0030)$ & $(0.0634)$ \\
\hline & -21.424 & 6.6222 & $-0.663 * * *$ & -0.3670 & 0.5987 & -5.4426 \\
\hline \multirow[t]{2}{*}{$\mathrm{C}$} & [12.578] & [5.8505] & {$[0.2794]$} & {$[0.2256]$} & [0.3229] & [3.3340] \\
\hline & $(0.1871)$ & $(0.3400)$ & $(0.0984)$ & $(0.2022)$ & $(0.1608)$ & $(0.2011)$ \\
\hline
\end{tabular}

Note: $*, * * \& * * *$ represent $1 \%, 5 \% \& 10 \%$ level of significance respectively.

\section{Conclusion and Recommendation}

The main aim of the study to investigate the effect of indirect taxes on economic growth in the Asian Countries and used the panel data of 12 Asian countries for period of 1996 to 2018 and used PMG techniques to estimate the model. This study found that the gross capital formation, political stability, labor force, inward FDI, human capital, and taxes on goods and services (TGS) have positive while domestic credit to private investment have negative and significant effect on economic growth in the long run. The labor force, political stability and taxes on goods and services (TGS) have encouraging and significant consequence on economic growth in the short run while gross capital formation, human capital, inward FDI, domestic credit to private sector have insignificant consequence on economic growth 
in the short run. The taxes on goods and services (TGS) have encouraging and significant effect on economic growth in Bangladesh, Iran, Nepal, Turkey, Indonesia, Malaysia, Thailand and Bhutan while have adverse and significant consequence on economic growth in Pakistan, Sri Lanka, Philippine and Japan. This study concluded that the indirect taxes have positive and significant effect on economic growth in the Asia. Moreover, the effect of indirect taxes was very from country to country dues its economic situation. The Political stability have also significant effect on economic growth. This study recommended that indirect taxes are more helpful to collect the revenue with the presences of political stability.

\section{References}

Abiola, J., \& Asiweh, M. (2012). Impact of tax administration on government revenue in a developing economy-a case study of Nigeria. International Journal of Business and Social Science, 3(8), 99-113.

Arisoy, I., \& Unlukaplan, I. (2010). Tax composition and growth in Turkey: An empirical analysis. International Research Journal of Finance and Economics, 59, 51-61.

Arnold, J.M., Brys, B., Heady, C., Johansson, Å., Schwellnus, C., \& Vartia, L. (2011). Tax policy for economic recovery and growth. The Economic Journal, 121(550), F59-F80.

Atkinson, A.B., \& Stiglitz, J.E. (1976). The design of tax structure: direct versus indirect taxation. Journal of public Economics, 6(1-2), 55-75.

Ayuba, A.J. (2014). Impact of non-oil tax revenue on economic growth: The Nigerian perspective. International Journal of Finance and Accounting, 3(5), 303-309.

Azam, M. (2019). Energy and economic growth in developing Asian economies. Journal of the Asia Pacific Economy, 1-25.

Baiardi, D., Profeta, P., Puglisi, R., \& Scabrosetti, S. (2017). Tax policy and economic growth: does it really matter? International Tax and Public Finance, 26(2), 282-316.

Bâzgan, R.-M. (2018). The impact of direct and indirect taxes on economic growth: An empirical analysis related to Romania. Proceedings of the international conference on business excellence, 12(1), 114-127. doi: DOI: $10.2478 /$ picbe-2018-0012

Cox, G.W., \& Weingast, B.R. (2018). Executive constraint, political stability, and economic growth. Comparative Political Studies, 51(3), 279-303.

Cremer, H., \& Gahvari, F. (1995). Uncertainty, optimal taxation and the direct versus indirect tax controversy. The Economic Journal, 105(432), 1165-1179. 
Cremer, H., Pestieau, P., \& Rochet, J.C. (2001). Direct versus indirect taxation: the design of the tax structure revisited. International Economic Review, 42(3), 781-800.

Dahlby, B. (2003). Restructuring the Canadian tax system by changing the mix of direct and indirect taxes. Tax Reform in Canada: Our Path to Greater Prosperity, 77-108.

Devarajan, S., Swaroop, V., \& Zou, H.-f. (1996). The composition of public expenditure and economic growth. Journal of monetary economics, 37(2), 313-344.

Emran, M.S., \& Stiglitz, J.E. (2005). On selective indirect tax reform in developing countries. Journal of public Economics, 89(4), 599-623.

Feng, Y. (1997). Democracy, political stability and economic growth. British Journal of Political Science, 27(3), 391-418.

Greenidge, K., \& Drakes, L. (2010). Tax policy and macroeconomic activity in Barbados. Money Affairs, 23(2), 182-210.

Harberger, A. (1964). Taxation, resource allocation, and welfare The role of direct and indirect taxes in the Federal Reserve System (pp. 25-80): Princeton University Press.

Ilaboya, O., \& Mgbame, C. (2012). Indirect tax and economic growth. Research Journal of Finance and Accounting, 3(11), 70-82.

Im, K.S., Pesaran, M.H., \& Shin, Y. (2003). Testing for unit roots in heterogeneous panels. Journal of econometrics, 115(1), 53-74.

Kadir, J.A., Idris, M., \& Mohamed, Z. (2011). Relationship between indirect taxes to Gross National Product (GNP): Malaysian case. Business Management Quarterly Review, 2(1), 28-37.

Kao, C. (1999). Spurious regression and residual-based tests for cointegration in panel data. Journal of econometrics, 90(1), 1-44.

Karim, N., \& Khan, F. (2018). The Effect Of Investment In Education On Socio-Economic Development Of Pakistan. Pakistan Journal of Humanities \& Social Science Research, 01(02).

King, R.G., \& Rebelo, S. (1990). Public policy and economic growth: developing neoclassical implications. Journal of political Economy, 98 (5, Part 2), S126-S150.

Kneller, R., Bleaney, M.F., \& Gemmell, N. (1999). Fiscal policy and growth: evidence from OECD countries. Journal of public Economics, 74(2), 171-190.

Laura, U.A. (2019). Impact of Indirect Taxation on Economic Growth in Nigeria. International Journal of Advanced Engineering Research and Science, 6(5), 54-61. doi: https://dx.doi.org/10.22161/ijaers.6.5.8

Levin, A., Lin, C.-F., \& Chu, C.-S. J. (2002). Unit root tests in panel data: asymptotic and finite-sample properties. Journal of econometrics, $108(1), 1-24$. 
Maddala, G.S., \& Wu, S. (1999). A comparative study of unit root tests with panel data and a new simple test. Oxford Bulletin of Economics and statistics, 61(S1), 631-652.

Madsen, J., \& Damania, D. (1996). The macroeconomic effects of a switch from direct to indirect taxes: an empirical assessment. Scottish Journal of Political Economy, 43(5), 566-578.

Musaga, B. (2007). Effects of taxation on economic growth:(Uganda's Experience: 1987-2005). Makerere University. Retrieved from http://dspace3.mak.ac.ug/handle/10570/3134

Naito, H. (2007). Atkinson-Stiglitz Theorem with Endogenous Human Capital Accumulation. The BE Journal of Economic Analysis \& Policy, 7(1), 1-31.

Okoye, P.V., \& Ezejiofor, R. (2014). The impact of e-taxation on revenue generation in Enugu, Nigeria. International of Advanced Research, 2(2), 449-458.

Ormaechea, M.S.A., \& Yoo, M.J. (2012). Tax composition and growth: A broad cross-country perspective: Fiscal Affairs Department , International Monetary Fund.

Pesaran, M., Shin, Y., \& Smith, R. (1997). Pooled estimation of long-run relationships in dynamic heterogeneous panels: University of Cambridge. Department of Applied Economics.

Pesaran, M., Shin, Y., \& Smith, R.P. (1999). Pooled mean group estimation of dynamic heterogeneous panels. Journal of the American Statistical Association, 94(446), 621-634.

Poterba, J.M., Rotemberg, J.J., \& Summers, L.H. (1985). A tax-based test for nominal rigidities. National Bureau Of Economic Research Working Paper Series, Working Paper No. 1621, 1-52.

Rehman, Z.U., Tariq, M., \& Khan, M.A. (2018). The Role of Human Capital in Economic Development in the Selected Central Asian Countries. Dialogue (Pakistan), 13(3).

Scarlett, H.G. (2011). Tax policy and economic growth in Jamaica. Research Services Department, Research\&Economic Programming Division, Bank of Jamaica, 1-25. doi: http://boj.org.jm/uploads/pdf/papers_pamphlets/papers_pamphlets_Tax_ Policy_and_Economic_Growth_in_Jamaica.pdf

Solow, R.M. (1956). A contribution to the theory of economic growth. The quarterly journal of economics, 70(1), 65-94.

Yanikkaya, H., \& Turan, T. (2020). Tax structure and economic growth: do differences in income level and government effectiveness matter? The Singapore Economic Review, 65(01), 217-237. 